\title{
Prospective Teachers' Perceptions of Barriers to Technology Integration in Education
}

\author{
Emre Dinc \\ Pennsylvania State University, United States \\ ORCID: 0000-0002-1838-4044
}

\begin{abstract}
This study examined the thoughts of preservice teachers about technology integration and collected their ideas about possible barriers to technology integration in education. With this aim, the participants were asked two key questions which are (1) "What does 'Technology Integration in Education' mean to you?" and (2) "What might be the possible barriers to technology integration in education?". A total of 76 preservice teachers, who took the course "Integrating Technology in Education" during their Elementary Teacher Education program took part in the study. The data were analyzed by using descriptive analysis method in this qualitative study. As a result of the study, it was revealed that preservice teachers have critical perceptions related to technology integration, such as effective use of technology, inclusion of technology in the course curriculum, increasing engagement, visualizing the course content, working with administrators to integrate technology, and being able to teach with technology that cannot be taught beforehand. As for the external and internal barriers, the participants commented that lack of funding/budget, lack of equipment, lack of ability, and time are major barriers to technology integration in education. Unlike the other studies in the relevant literature, preservice teachers stated parents and security as barriers to integrating technology in education.
\end{abstract}

Keywords: Technology integration; Technology use in education; Prospective teachers; Barriers to technology use; Descriptive analysis

\section{Introduction}

\section{Technology in Education}

Nobody doubts that technology has revolutionized many aspects of human life. Impossible has become possible, and the quality of human life has been improved drastically. Technology has been affecting every aspect of our lives. From this point of view, education is not an exceptional field, and it has been touched by technology's magic, as well.

In many studies, technology's effect has been examined on education. Morgan and Ritter (2002) found that computer-based curriculum increases student performance in the classroom and affects students' attitudes positively when computers are used as learning tools. As a result of their research, Lowther, Strahl, Inan, and Bates (2008) stated that students are positively affected by the use of technology. This led to more use of student-centered activities, more attention to the lesson, and more interest in the subjects. The purpose of the study conducted 
by Gulek and Demirtas (2005) was to examine the effect of technology use on student achievement. As a result, students' test scores and writing skills increased with the help of technology use. A study conducted with students with disabilities and their teachers revealed that technology use improved disabled students' writing quality and quantity. Technology also has a positive effect on their engagement, motivation, ability to work independently, interaction with peers and teachers, and class preparation. The technology was perceived as beneficial to many students with disabilities and their teachers (Harris \& Smith, 2004). Students also increase their technology proficiency with the technology use in lessons, and technology improves learning experiences and provides opportunities and resources for teaching and learning (Lei \& Zhao, 2008). Islam and Gronlund (2016) carried out a literature review regarding the integration of computer technologies in schools. They reported that students' engagement, motivation, computing skills, and the ability to study independently and collaboratively were improved. It was also noted that teachers benefitted from flexible teaching, collaboration, and professional development. Dinç (2017) stated that technology provides visualization for the content, and this can be used by teachers to motivate students, who are already accustomed to using technology, to engage with the content. He also alleged that technology makes meaningful learning possible with different types of technologies in the learning environment. National Research Council (2000) indicated that making the content and the ideas visible ensures to see the learners' understanding. With this, teachers can guide their students according to their understanding and make sure meaningful learning.

In the US, the Education Technology Plan (U.S. Department of Education, 2017) stated that technology has rapidly changed in access to technology in the classroom, the variety and the cost of technology, the emphasis on the data security, the importance given to technology in education by the leaders, and the significance of teacher learning to integrate technology into education. This plan aimed to provide insight and recommendations primarily to teachers, people who are responsible for teacher learning, policymakers, and education leaders regarding equity and accessibility. By equity, the plan authors meant access to educational opportunities by all students with a focus on the achievement gaps and removing the barriers. By accessibility, they meant the design of the materials, devices, and environments to make sure students enable to access the content and activities. It was alleged that technology could be the answer for the inequity and inaccessibility with features such as text-to-speech, speech-to-text, audio, and digital formats, and differentiate instruction. In a section of the plan, it was pointed out that having a technology-enhanced environment is not enough; educators need to have the knowledge and abilities to utilize these technologies at full capacity. Having a technologyenhanced environment and educators who are able to use technology in a meaningful way requires leaders who need to take action and create a vision in order to find answers for all learners needs and have a plan to take the vision into practice. Last but not least, technology infrastructure is a must to make sure the learning, teaching, and assessment by technology. High-speed connectivity, available devices for learners and teachers, digital learning content, professional development resources for educators and education leaders can be given as examples of elements for the technology infrastructure.

\section{Technology Integration}

There are different views on utilizing technology in education. Reigeluth and Joseph (2002) provide two notions, which are technology integration and technology transformation. According to Reigeluth and Joseph (2002), technology integration is about how to use technology to support the way of teaching, while technology transformation is the fundamental 
changes in the way of teaching things that cannot be taught before. Ertmer (2005) sees technology integration very close to the definition of technology transformation by Reigeluth and Joseph (2002). According to Ertmer (2005), technology integration should aim in succeeding more sophisticated and authentic goals rather than decreasing the time to achieve a goal. In Coleman's (2015) study, middle school mathematics teachers defined technology integration as "using technology to supplement and drive instruction" and as "visuals for the students." Rehmat and Bailey (2014) defined technology integration in the context of their study with the help of TPACK model as "The appropriate selection and use of technology within a science lesson or unit to facilitate or enhance student learning of the content." Also, Cullen and Greene (2011) in the context of their study defined technology integration as "The use of technology in a teacher's regular teaching and curricular plans." Considering different views for technology integration and the TPACK model, which is the knowledge that needs to be acquired by teachers to integrate and use technology, understanding how preservice teachers define and perceive the term has vital importance. Teachers stated that technology makes their students more engaged, and this affects students' achievement in the class (Kay, Knaack, \& Petrarca, 2009). Saine (2012) stated that the use of technology makes students more engaged and creative. Pennington (2010) also noted that technology improves the learning of students with special needs due to its ability to make the content visual. Additionally, some studies (Scalise, 2016; Shaltry, Henriksen, Wu, \& Dickson, 2013) showed that technology supports and creates collaboration and engagement.

\section{Barriers to Technology Integration}

Ertmer (1999) categorized two classes of barriers, which are first-order and second-order barriers. First-order barriers are external factors including access to technology, time, support, and professional development training, and second-order barriers are internal factors, which are teacher's confidence in using technology and their belief in the usefulness of technology use in education. As for external factors, Hechter and Vermette (2013) reported that the main obstacles preventing teachers' technology integration are lack of resources, lack of time, lack of training opportunities, and lack of funding and support. Keengwe, Onchwari, and Wachira (2008) summarized that poor training, lack of equipment, lack of time, poor administrative support, and technical problems are the main barriers to technology integration. Prasojo, Habibi, Yaakob, Mukminin, Haswindy, and Sofwan (2019) studied school principals' perceptions and resulted in that major external barriers to integrating technology are lack of funding and lack of professional development. Sheninger (2014) also noted that principals had an effect on incorporating technology in the classroom. Additionally, Ertmer and Ottenbreit-Leftwich (2013) pointed out that the number of technological tools, maintenance service, technical support, and providing training for new tools are also external factors. Nikolopoulou and Gialamas (2015) also found that lack of funding, lack of technical support, lack of administrative support, poor training, lack of equipment, and lack of access to the equipment reduce the level of teachers' technology use. Hur, Shannon, and Wolf (2016) reported that the lack of technological equipment, not enough number of computer labs, and Internet connection problems are some factors that affect technology integration in the classroom negatively. The research stated that lack of in-service training, lack of equipment, lack of technology plans, lack of appropriate software, and lack of computer labs are some barriers reported by teacher educators, prospective teachers, and deans (Goktas, Yildirim, \& Yildirim, 2009). Kilinc, Tarman, and Aydin (2018) found that according to in-service teachers, lack of technology, lack of access, and lack of administrative and technical support are major barriers to integrate technology. As for professional development in technology use, Blocher, Armfield, Sujo-Montes, Tucker, and Willis (2011) stated that 
professional development influenced teachers' technology use positively, and studies said that professional development significantly affects technology integration (Bhasin, 2012; Kopcha, 2012; Scott \& Mouza, 2007). However, Hur, Shannon, and Wolf (2016) found that professional development does not have a significant effect on technology use and teachers' self-efficacy; instead, it affects teachers' perceptions regarding the benefit of technology integration and their self-confidence significantly. Accordingly, self-confidence in technology use positively affects technology integration (Koh \& Frick, 2009). However, Duhaney (2001) found that some teachers are unwilling to integrate technology in their classroom due to lack of interest and motivation.

Ertmer, Ottenbreit-Leftwich, Sadik, Sendurur, and Sendurur (2012) noted that external barriers were still in play; however, teachers' belief and confidence level in technology integration are main factors to overcome resource and access barriers. In the same study, authors claimed that knowledge and skills, which are more effective to modify attitudes and beliefs in order to integrate technology should be increased instead of exerting more effort to remove first-order (external) barriers. Wong (2015) and Miranda and Russell (2012) conducted studies and discovered that teachers' belief that using technology is beneficial to reach the determined goals affected their technology use in their instruction. Many teachers want to integrate technology into their classroom instruction (Aslan \& Zhu, 2015; Kimmons \& Hall, 2016), but they do not have enough knowledge to use technology effectively (Mishra \& Koehler, 2006; Vatanartiran \& Karadeniz, 2015) and they lack self-efficacy for integrating technology in education (MooreHayes, 2011). Alkhawaldeh and Menchaca (2014) reported that lack of ability and confidence are factors that have an effect on technology integration in education. Accordingly, Kim, Kim, Lee, Spector, and DeMeester (2013) highlighted that teachers' technology integration practices affect their beliefs about effective ways of teaching. If teachers have technology integration experiences in education, their level of technology use increases (Kim et al., 2013). They feel more comfortable, and it affects their success in integrating technology. Considering studies (Ertmer, 1999; Wood, Specht, Willoughby, \& Mueller, 2008) stated that lack of comfort with the technology is a barrier to technology integration, having experiences with practices would help teachers be more comfortable and experienced in integrating technology. Lack of teacher confidence, resistance to change, and lack of vision (Keengwe, Onchwari, \& Wachira, 2008) and lack of teachers' knowledge and dependence on traditional teaching styles are internal barriers to technology integration (Prasojo et al., 2019).

\section{Purpose of the Study}

Technology integration in education has been studied for more than four decades (Lowther et al., 2008; Zehra \& Bilwani, 2016). Studies examined the technology integration practices, perceptions, and barriers to it throughout all this time. It should be noted that technology develops and progresses every minute every day. Therefore, people's ideas and possibilities regarding technology and technology integration are changing. Over time, new technology integration pathways are being explored, new ideas are being developed to remove barriers, new barriers are emerging, and opinions about the place of technology in education change.

This study was conducted to find out the current perceptions of preservice teachers about technology integration, their ideas about barriers to technology integration in education, and gaining insight about technology integration in education to improve the current practices.

First, courses at teacher training institutes have an impact on how preservice teachers see and understand technology integration in education. Abbitt's (2011) study showed that an 
educational technology course, which emphasizes the practical experiences is a need to improve preservice teachers' skills and abilities in terms of technology integration. Rehmat and Bailey (2014) pointed out that a course on education technology would be helpful for learners' understanding regarding technology integration. For this, thoughts of preservice teachers, who took a course related to technology integration should be investigated. In this way, teacher candidates' real ideas and thoughts related to technology integration can be reached.

Second, as seen from the studies mentioned in this research, there are differences in the perceptions regarding technology integration in the literature, and recent studies acknowledged that teachers are reporting some barriers to integrate technology in education. It is thought that teacher candidates' perceptions for technology integration will reveal their real thoughts about the term, and investigating their thoughts about the barriers to integrating technology in education will disclose how they see the process of technology integration and what they expect to face and overcome when they become a teacher after their teacher training.

In addition, in the 21st century Digital Age, knowing what teacher candidates think about technology integration in education has vital importance to improve the quality of education supported by technology. In this way, misunderstandings can be determined in advance, and misconceptions caused by faulty or missing prior knowledge can be prevented. For this reason, the research questions below guided the study:

- How do preservice teachers perceive technology integration in education?

- What are the ideas of preservice teachers about barriers to technology integration in education?

\section{Methodology}

\section{Participants}

This study was carried out with 76 volunteer preservice teachers at a university in the NorthEast part of the US. Criterion sampling method, which is one of the purposive sampling methods, was used to identify the participants. Criterion sampling method follows predetermined criteria for choosing cases in the study (Patton, 1990). Considering the purpose of the research, potential participants should have been preservice teachers and taken a course in relation to technology integration. Therefore, 76 preservice teachers, who took the course "Integrating Technology in Education" during their Elementary Teacher Education program took part in the study.

\section{Instrumentation}

In this study, first of all, a research form consisting of two open-ended questions was prepared to make sure to reveal preservice teacher's thoughts about technology integration and their ideas about barriers to technology integration in education. In order to determine the level of language, coverage, and the suitability of these two questions in terms of the purpose of this research, opinions of an expert in the field of education technology were taken, and studies conducted on this topic were examined. After that, these questions were rearranged in line with the previous studies and suggestions by the expert. The final form of two open-ended questions 
are (1) "What does 'Technology Integration in Education' mean to you?" and (2) "What might be the possible barriers to technology integration in education?"

\section{Data Collection}

Before handing out the research forms to the participants, it was explained that the purpose of the survey is not testing their knowledge on the topic; instead, collecting information regarding preservice teachers' thoughts and ideas about technology integration for academic purposes. For this reason, students were asked not to write their personal information on their answer sheets in order to reflect their true feelings and thoughts and to protect their confidentiality. Students were also asked to explain their thoughts and ideas in detail. After this explanation, 15 minutes were given to the students to be able to answer the questions on the research form. It was assumed that the participants provided their real thoughts to the questions on the answer sheets.

\section{Data Analysis}

The data were analyzed by using descriptive analysis method in this qualitative study. The aim of conducting qualitative analysis is to attempt to discover and determine the information from the collected data (Ozdemir, 2010). The obtained data were summarized and interpreted according to the previously identified themes in the descriptive analysis (Yildirim \& Simsek, 2003). In this study, some categories had been determined according to previous studies; but, when necessary, new categories were added during the analysis process. Therefore, it is possible to say that the creation of the categories is not only based on the questions asked but based on the views arising from the analysis of all the data. Examples of preservice teachers' responses were quoted directly.

\section{Validity and Reliability}

This study considered the conclusiveness, transferability, and confirmability strategies, and this consideration ensured the validity and reliability of the study (Yildirim \& Simsek, 2005).

In this study, conclusiveness and consistency were achieved by conferring to an expert. In this context, the answers were not only evaluated by the researcher but also consulted to an expert in the field to increase the quality of the research. Transferability was achieved by describing and interpreting the typical and changeable characteristics of the study in detail. Confirmability was tried to be performed by quoting from the data as much as possible and sufficient.

\section{Results}

First, preservice teachers' answers to the first question on the research form were examined. The purpose of the first question was to reveal the thoughts of preservice teachers about technology integration. Table 1 below shows that the perceptions of teachers about technology integration. 
Table 1. Preservice Teachers' Perceptions about Technology Integration

\begin{tabular}{lc}
\hline \multicolumn{1}{c}{ Perceptions } & $\mathbf{n}$ \\
\hline $\begin{array}{l}\text { Teaching and learning concepts, which is not possible to teach and learn } \\
\text { before can be learned and taught with the help of technology }\end{array}$ & 15 \\
\hline Supporting the instruction of the content and learning & 26 \\
\hline Increasing engagement with technology & 38 \\
\hline Making the content visible with the help of technological tools & 5 \\
\hline Effective use of technology & 64 \\
\hline Adding technology resources into the learning environment & 61 \\
\hline Technology integration in all subjects & 34 \\
\hline Technology integration should cover core subjects & 24 \\
\hline $\begin{array}{l}\text { A process that students, teachers, principals, and educational leaders exert } \\
\text { effort in order to increase the quality of education by technology }\end{array}$ & 2 \\
\hline
\end{tabular}

It is noteworthy that 15 (out of 76) participants in the study expressed their thoughts about technology integration in education as teaching and learning concepts, which is not possible to teach and learn before can be learned and taught with the help of technology. One of the participants stated that previously only drawings or handmade objects were used for teaching 3D objects, and they both did not fully support the learning and took time. He emphasized that 3D objects can now be taught without time or material problems with the help of technology. Another one stated that with the help of online programs, they are able to show the change in the area or volume of a geometric object dynamically. Examples of the views given to the question:

... means using technology to enhance student learning and mastering of concepts that otherwise wouldn't be possible. It is about expanding opportunities to help best teach out students.

... means that technology is brought into classroom and used in all subjects as much as possible. Tech can be used in math and science today that may not have been true in the past. Programs that make dynamic objects possible is a way to teach the content that cannot be taught in such an effective way before ...

Twenty-six (out of 76) preservice teachers in the study noted that technology integration means supporting the instruction of the content and learning of students in the classroom. Preservice teachers indicated integrating technology in education as a tool, not a purpose to use it. It also helps teachers to guide their students and to increase the understanding of the topic. Examples of the views given to the question:

... is teaching lessons in all subject areas using technology to help guide students. Technology is a tool in the environment to guide students and teachers to reach the desired outcomes...

... means using technology in a lesson in a way that supplement the content and helps people better understand information.

... means using tools to aid children in their learning process. Teachers use technology to help students and further lessons. 
Another key finding of this study was that technology integration means to half of the participants increasing engagement with technology in the classroom. According to their answers, half of the participants saw technology integration as a way to help students to be engaged. One preservice teacher asserted that students now demand technology in every aspect of their lives. That's why having technology in the process of learning increases the students' interest in the lesson, and therefore, technology motivates the students to engage more. Examples of the views given to the question:

... means more than just using technology. You need to ensure that technology is fully integrated into your lesson. We must use technology with a purpose. It should benefit your lesson. It can be a way to engage students.

... Technology increases interest to the topic and creates motivation to students and teachers. It provides an engaging opportunity to teach lessons to students. I always found myself to be more involved when technology was used because more students were able to participate rather than just listening to the teacher talk.

... Using technology in the classroom and integrating it into your lessons invites your students to see how technology can help them learn keeping them engaged.

Five (out of 76) participants stated that technology integration means making the content visible with the help of technological tools. The integration of technology in education takes form as the visualization of difficult-to-understand subjects in their minds, and this contributes to the learning of students. Examples of the views given to the question:

... effective way of technology integration ensures helping students visualize concepts and motivating them in classroom to learn more.

... means a way to make more engaging and creative lessons. Technology such as PowerPoint can be a more informative way to teach students when done correctly. PowerPoints allow the students to visualize the information, and it can further students learning by adding images, graphic organizers, and even videos.

... Students learn better when they see things that they cannot in absence of technology. Seeing and experiencing are the best ways to learn and understand. Students can even get on a spaceship virtually in the classroom thanks to the integration of technology in education.

Sixty-four (out of 76) of the preservice teachers in the study indicated that technology integration is the effective use of technology in education. The effective use of technology in some lessons and subjects in the curriculum implies technology integration to these teacher candidates. They stated that the use of technology should be in favor of students learning. Technology use should be for the sake of learning, not for the sake of technology. Many participants noted that if the technology is not used to increase student learning and understanding, it is not different from the learning without technology, and there is no effect of having technology in the learning environment. Examples of the views given to the question:

... means to me the meaningful use of technology in class curriculum that supports student learning. ... 
...means to have technology in your classroom and using it to the best of your ability when conducting lessons. ... a way for students to advance their knowledge in better ways.

...means using technology as a way to support and enhance education. When tech is integrated that means it is a part of the classroom/lesson from the beginning, not just an afterthought.

Sixty-one (out of 76) participants stated that adding technology resources into the learning environment can be considered as technology integration. This is one of the common thoughts about technology integration. However, the participants here indicated clearly that the teacher should determine technological resources that need to be added to the learning environment. Moreover, they indicated that teachers need to be knowledgeable to incorporate technology resources into the classroom and choose what kind of resource would be effective to use. Examples of the views given to the question:

... means to me utilizing the technological resources, which are chosen by the teacher in the classroom setting and school system as a whole. ...

... giving opportunities to use technology along with materials and lessons you devise as a teacher....

...means to me that teachers incorporate useful technology resources such as online programs, programming or apps into their lessons in order to benefit student learning in all content areas.

Another perception that preservice teachers had regarding technology integration in education is that thirty-four (out of 76) participants highlighted technology integration in all subjects; twenty-four (out of 76) participants noted that it should cover core subjects in education. Examples of the views given to the question:

... is the use of modern technology to aid and improve education of core subjects while simultaneously giving students experience using modern tools....

... means that technology is included in the core subjects of the "everyday" classroom curriculum, such as math, English, and science. ...

... means using different technological resources to enhance learning in all content areas.

... is utilizing any form of technology available to a classroom setting and incorporating it into lessons of all subjects....

According to two (out of 76) of the participants, technology integration is a process that students, teachers, principals, and educational leaders exert effort in order to increase the quality of education by technology. Examples of the views given to the question:

... means not only teaching students the subjects with the help of technology, but also bringing technology into classrooms with the support of principals and educational leaders. ... 
... is increasing the use of technology in schools by students, teachers, and principals as it pertains to their career....

Second, the preservice teachers' answers to the second research question were examined. Here to see their ideas about the barriers to technology integration clearly, the ideas were categorized under some main topics according to previous studies. Table 2 shows sample responses and the frequencies of the categories regarding the barriers that preservice teachers stated in their answers.

Table 2. Summary of Answers to the Second Research Question

\begin{tabular}{|c|c|c|c|}
\hline $\begin{array}{l}\text { First-order barriers } \\
\text { (external) }\end{array}$ & $f$ & $\%$ & Sample response \\
\hline Time & 52 & 68.4 & $\begin{array}{l}\text { to integrate technology across subjects is } \\
\text { something that takes time for teachers. }\end{array}$ \\
\hline lack of equipment & 68 & 89.5 & $\begin{array}{l}\text {... school may not have laptops and smartboards, } \\
\text { and in that case, it will be difficult to integrate } \\
\text { technology. }\end{array}$ \\
\hline $\begin{array}{r}\text { poor administrative } \\
\text { support }\end{array}$ & 17 & 22.4 & $\begin{array}{l}\text { Another barrier could be administrators' } \\
\text { openness to technology integration. }\end{array}$ \\
\hline $\begin{array}{r}\text { poor professional } \\
\text { development }\end{array}$ & 36 & 47.4 & $\begin{array}{l}\text {... might be lack of training for teacher on how to } \\
\text { use and integrate technologies into lessons. }\end{array}$ \\
\hline $\begin{array}{r}\text { lack of } \\
\text { funding/budget }\end{array}$ & 71 & 93.4 & ... may include lack of monetary support. \\
\hline lack of access & 26 & 34.2 & $\begin{array}{l}\ldots \text { could be not having access to the technology } \\
\text { needed, ... }\end{array}$ \\
\hline parents & 8 & 10.5 & $\begin{array}{l}\text { Some parents do not want their kids using } \\
\text { technology in the classroom. }\end{array}$ \\
\hline security & 4 & 5.3 & $\begin{array}{l}\text {... another barrier may be internet safety issues, } \\
\text { in other word, unable to protect personal info. }\end{array}$ \\
\hline lack of maintenance & 18 & 23.7 & $\begin{array}{l}\ldots \text { have a problem with technology in the } \\
\text { classroom, poor technical support is a huge } \\
\text { missing. }\end{array}$ \\
\hline $\begin{array}{r}\text { reliability of } \\
\text { equipment }\end{array}$ & 35 & 46.1 & $\begin{array}{l}\text {... technology sometimes has glitches and does } \\
\text { not always work, and ... }\end{array}$ \\
\hline Total & 335 & & \\
\hline $\begin{array}{l}\text { Second-order } \\
\text { barriers (internal) }\end{array}$ & $f$ & $\%$ & Sample Response \\
\hline unwillingness & 31 & 40.8 & $\begin{array}{l}\text { Some educators are very closed to the idea of } \\
\text { integrating tech into lessons, ... they don't want } \\
\text { to change the way they teach. }\end{array}$ \\
\hline
\end{tabular}




\begin{tabular}{|c|c|c|c|}
\hline lack of confidence & 23 & 30.3 & ... fear of changing old ways of teaching ... \\
\hline lack of knowledge & 43 & 56.6 & $\begin{array}{l}\text {... limited information about tech, not knowing } \\
\text { how to process and use different tools and } \\
\text { programs. }\end{array}$ \\
\hline lack of ability & 53 & 69.7 & $\begin{array}{l}\text {... teachers' inability to effectively use the tech } \\
\text { equipment ... }\end{array}$ \\
\hline $\begin{array}{r}\text { lack of feeling } \\
\text { comfort }\end{array}$ & 21 & 27.6 & $\begin{array}{l}\text {... a teacher may not be comfortable enough to } \\
\text { incorporate it into her lesson. }\end{array}$ \\
\hline
\end{tabular}

Total 171

Preservice teachers' ideas about technology integration were categorized as first-order and second-order barriers. Participants provided 335 statements for first-order barriers and 171 statements for second-order barriers. Most of the participants commented that lack of funding/budget (93.4\%), lack of equipment (89.5\%), lack of ability (69.7\%), and time (68.9\%) were major barriers to technology integration in education. It must be stressed that some preservice teachers stated parents $(10.5 \%)$ and security $(5.3 \%)$ as barriers to technology integration in education.

\section{Discussion and Conclusions}

Taking the results of this study into consideration, preservice teachers have different views regarding technology integration in education, and they expected that many challenges are waiting for them in terms of technology integration when they begin teaching. This study, which investigates the preservice teachers' thoughts about technology integration and barriers to integrating technology in education, is significant in terms of revealing the current perceptions of preservice teachers.

According to the results of the answers given to the first question, preservice teachers explain the technology integration with the following headings: teaching and learning concepts, which is not possible to teach and learn before can be learned and taught with the help of technology (19.7\%), supporting the instruction of the content and learning (34.2\%), increasing engagement with technology (50\%), making the content visible with the help of technological tools (6.5\%), effective use of technology (84.2\%), adding technology resources into the learning environment(80.2), a process that students, teachers, principals, and educational leaders exert effort in order to increase the quality of education by technology (2.6\%), and in all subjects(44.7\%)/core subjects(31.5\%). It turns out, $19.7 \%$ of the preservice teachers in the study perceived technology integration as Reigeluth and Joseph's (2002) technology transformation and Ertmer's (2005) technology integration concepts, while $80.2 \%$ of them saw technology integration as adding technological tools into the learning setting. This number of participants (80.2\%) shows that preservice teachers' perceptions in this study coincide with the definition of technology integration provided by Rehmat and Bailey (2014). Appropriate selection of technology within a lesson to use and accordingly bringing appropriate technology into the learning setting correspond technology integration in the eyes of teacher candidates. In addition, middle school teachers defined technology integration as using technology to support 
and drive instruction (Coleman, 2015), in parallel, preservice teachers in this study stated that technology supports teachers' instruction and students' learning. Participants believed that support the instruction with technology will increase the understanding of the content. This supports the results of the study conducted by Gulek and Demirtas (2005), which stated that technology use increases student achievement. Also, seeing technology integration as a way to visualize the content was reported by only 5 participants. This finding supports studies (Coleman, 2015; Dinc, 2017; Pennington, 2010), which stated technology integration as a way of visualization. Considering the results of the other studies (Coleman, 2015; Cullen \& Greene, 2011) in the literature, as expected, teacher candidates stated that they perceive technology integration as effective use of technology. The two participants emphasized that it was not only the teacher's duty to bring technology into the educational environment in the perceptions of teacher candidates in technology integration, but also the administrators should be involved in this process. It is noteworthy that the number of participants making this emphasis is low. However, these two preservice teachers' statements showed that leaders should take responsibility and play a role in creating the necessary vision and turning it into practice, as stated in the Educational Technology Plan (U.S. Department of Education, 2017). Teachers' perceptions about technology integration related to engagement support the results of studies conducted before (Islam \& Gronlund, 2016; Kay, Knaack, \& Petrarca, 2009; Saine, 2012). Technology integration increases engagement in education, and accordingly, student performance is getting increased. Besides, it is also noteworthy that no participant mentions collaboration. There are studies in the literature that technology integration positively affects collaboration, but it is an important detail not to be seen in the perceptions of preservice teachers regarding technology integration. This may imply that collaborative learning is not given the necessary importance in the training of preservice teachers.

The most remarkable detail was that some teacher candidates considered technology integration suitable for all subjects, but some of them indicated that technology integration should be only for core subjects. Some studies (Hennessy, Ruthven, \& Brindley, 2007) solely focused on technology integration in core subjects (English, Mathematics, and Science), while others (Foster, Kelley, Pritz, \& Hodes, 2011) stated that teachers of all subjects should use technology to increase the effectiveness of the instruction. While some of the preservice teachers in this study thought like the researchers who believe that technology integration should be in the basic courses, some of them looked at the situation like the researchers who say that it is necessary to integrate technology in all courses.

As a result of this study, preservice teachers' ideas about external barriers to technology integration has been revealed. The current status of preservice teachers' perceptions regarding barriers was investigated, and the results showed that preservice teachers still have concerns about the problems they would face when they start teaching although some studies noted that some of the barriers had been removed partially from the learning environments. Report on the recovery of situations that impede technology integration is about external barriers, such as access to computers and the Internet (Gray, Thomas, \& Lewis, 2010). However, it is important that preservice teachers living in the US, a developed country, thought that they might face problems in lack of equipment. This finding of this research supports the results of the study conducted by Hur, Shannon, and Wolf (2016). It was observed in this study that lack of funding/budget was found as the main barrier to integrating technology in education as in many previous studies (Hechter \& Vermette, 2013; Keengwe, Onchwari, \& Wachira, 2008; Nikolopoulou \& Gialamas, 2015; Prasojo et al., 2019). Preservice teachers' another perception about barriers to technology integration was lack of time. Most of the participants indicated their concerns related to lack of time. According to their perceptions of technology integration 
revealed from the first question, it is obvious that preservice teachers consider technology integration as effective use of technology, inclusion of technology in the course curriculum, increasing engagement, visualizing the course content, working with administrators, and being able to teach with technology that cannot be taught beforehand. It is obvious that time is required to manage all. From this perspective, it is quite reasonable for them to see the lack of time as a barrier to technology integration.

Although there are different views about the effect of professional development (Blocher et al., 2011; Hur, Shannon, \& Wolf, 2016; Kopcha, 2012; Scott \& Mouza, 2007), poor professional development is accepted as a barrier to technology integration (Ertmer, 1999; Ertmer \& Ottenbreit-Leftwich, 2013; Keengwe, Onchwari, \& Wachira, 2008; Prasojo et al., 2019). This idea of preservice teachers approves other studies that found time as a barrier (Ertmer, 1999; Hachter \& Vermette, 2013; Keengwe, Onchwari, \& Wachira, 2008) because one of the reasons for poor professional development could be lack of time. Besides, other external barriers, which are poor administrative support (Kilinc, Tarman, \& Aydin, 2018; Nikolopoulou \& Gialamas, 2015; Sheninger, 2014), lack of access (Ertmer \& Ottenbreit-Leftwich, 2013; Goktas, Yildirim, \& Yildirim, 2009; Hur, Shannon, \& Wolf, 2016; Kilinc, Tarman, \& Aydin, 2018; Nikolopoulou \& Gialamas, 2015), lack of maintenance (Ertmer \& Ottenbreit-Leftwich, 2013; Kilinc, Tarman, \& Aydin, 2018; Nikolopoulou \& Gialamas, 2015), and reliability of equipment (Hur, Shannon, \& Wolf, 2016; Keengwe, Onchwari, \& Wachira, 2008) hold significant places in preservice teachers' statements.

Unlike the other studies in the literature, preservice teachers stated that parents and security could be barriers to technology integration in this research. Some parents are against using technology in the classroom (Grunwald Associates LLC., 2013) and the security flaw in the Internet could be the reason for those statements. Privacy ethics is also a very recent unethical action today. Drake (2016) pointed out that ethics has a significant influence on information privacy. As he cited from studies by Stutzman, Gross, and Acquisti (2013), Belanger and Crossler (2011), and Smith, Dinev and Xu (2011), the computer technology's capability to store, share and match personal information over databases and networks causes the ethics of privacy violation to be the center of attention. Therefore, some parents are concerned about security and privacy issues, and they are not in favor of using technology in education.

The preservice teachers identified many external barriers, and their statements showed that internal barriers are negatively effective in technology integration, either. The statements related to internal barriers are gathered mostly under these two: lack of knowledge and lack of ability. These results supported the studies conducted before (Alkhawaldeh \& Menchaca, 2014; Mishra \& Koehler, 2006; Prasojo et al., 2019; Vatanartiran \& Karadeniz, 2015). With the help of adequate professional development programs supported by practices, necessary and sufficient knowledge, skills, and experience may be gained. In this way, consistent with the study conducted by Wood et al. (2008), preservice teachers will feel more comfortable integrating technology in education. Moreover, the participants commented that lack of confidence is another barrier, and this supports the results of studies of Alkhawaldeh and Menchaca (2014) and Keengwe, Onchwari, and Wachira (2008). The fact that the statements grouped as unwillingness are too high to be significant is important because of results in the previous study (Prasijo et al., 2019). As understood from the statements, the reason for unwillingness could be resistance to change (Keengwe, Onchwari, \& Wachira, 2008) the way teachers teach.

As indicated in the Education Technology Plan (U.S. Department of Education, 2017), teachers need to be knowledgeable about how to use technology appropriately in the classroom, and 
teachers and learners should be provided necessary technological devices, the Internet, and the digital content. Bill \& Melinda Gates Foundation (2012) reported that many teachers are complaining about the lack of training in technology integration in education. Although teachers are not the only responsible for all technology use in education, their effect on student learning cannot be denied (Rowan, Correnti, Miller, 2002). However, teachers have challenges and difficulties in teaching. The presence of technology is not the solution in every challenge and difficulty in the learning environment, but technology has the power to remove barriers for equity and accessibility. That is why authors of the Education Technology Plan (U.S. Department of Education, 2017) recommended professional learning experiences generated by technology for preservice teachers to ensure the improvement in teaching, assessment, and instructional practices. Research showed that professional development training for preservice teachers increases their perception regarding utilizing technology (Akkaya, 2016). As preservice teachers are the ones who teach the young generation in the future, they need to be knowledgeable, experienced, and skillful regarding how to integrate technology education, and their quality of training is significant to adopt technology use in their teaching (Drent \& Meelissen, 2008). To overcome these barriers, a strong technology plan and professional development opportunities are necessary for learning environments. In order to prepare a proper technology plan and professional development opportunities, preservice teachers' perceptions regarding technology integration should be considered. Additionally, the reasons for parents and security barriers should be investigated in detail for further studies. It is important to produce solutions for these barriers. For this reason, seminars on technology in education can be organized for parents, and parents' ideas can be taken while the technology plan is being prepared.

\section{Limitations and Recommendations}

The findings of this study have to be seen in the light of some limitations. First, a survey including two open-ended questions is the only method to collect data in order to analyze the perceptions about technology integration and ideas about barriers to integrating technology in education. Admittedly, a face-to-face interview with the help of a video-recorder and focus groups in addition to the survey would create more data to analyze, and the findings would be more comprehensive. Second, data were collected from a group of preservice teachers in the Elementary Education Program so the findings cannot be generalized to a larger population; however, the results are transferable to other settings.

\section{References}

Abbitt, J. T. (2011). An investigation of the relationship between self-efficacy beliefs about technology integration and technological pedagogical content knowledge (TPACK) among preservice teachers. Journal of Digital Learning in Teacher Education, 27(4), 134143.

Akkaya, R. (2016). Research on the development of middle school mathematics pre-service teachers' perceptions regarding the use of technology in teaching mathematics. Eurasia Journal of Mathematics, Science \& Technology Education, 12(4), 861-879.

Alkhawaldeh, N. I. \& Menchaca, M. (2014). Barriers to utilizing ICT in education in Jordan. International Journal on e-Learning, 13(2), 127-155. 
Aslan, A. \& Zhu, C. (2015). Pre-service teachers' perceptions of ICT integration in teacher education in Turkey. The Turkish Online Journal of Educational Technology, 14(3), 97110.

Belanger, F. \& Crossler, R. E. (2011). Privacy in the digital age: A review of information privacy research in information systems. MIS Quarterly, 35(4). 1017-1041.

Bhasin, B. (2012). Integration of information and communication technologies in enhancing teaching and learning. Contemporary Educational Technology, 3(2), 130-140.

Bill \& Melinda Gates Foundation. (2012). Innovation in education: Technology \& effective teaching in the U.S. Seattle, WA: Author.

Blocher, J. M., Armfield, S. W., Sujo-Montes, L., Tucker, G., \& Willis, E. (2011). Contextually based professional development. Computers in the Schools, 28, 158-169.

Coleman, P. (2015). Middle school mathematics teachers' perspective of technology integration: A qualitative case study (Unpublished dissertation). College of Education, Walden University, Minnesota, United States.

Cullen, T. A. \& Greene, B. A. (2011). Preservice teachers' beliefs, attitudes, and motivation about technology integration. Journal of Educational Computing Research, 45(1), 29-47.

Dinc, E. (2017). Differentiated learning environment - A classroom for quadratic equation, function, and graphs. In D. G. Sampson, J. M. Spector, D. Ifenthaler, \& P. Isaias (Eds.), CELDA 2017 Cognition and exploratory learning in digital age (pp. 237-240). Algarve, Portugal: International Association for Development of the Information Society. Retrieved on 20 May 2019 from https://files.eric.ed.gov/fulltext/ED579395.pdf

Drake, J. R. (2016). Asking for Facebook logins: An egoist privacy. Journal of Business Ethics, 139(3), 429-441.

Drent, M. \& Meelissen, M. (2008). Which factors obstruct or stimulate teacher educators to use ICT innovatively? Computers \& Education, 51, 187-199.

Duhaney, D. C. (2001). Teacher education: preparing teachers to integrate technology. International Journal of Instructional Media, 28(1), 23-30.

Ertmer, P. A. (1999). Addressing first- and second-order barriers to change: Strategies for technology integration. Educational Technology Research and Development, 47(4), 4761.

Ertmer, P. A. (2005). Teacher pedagogical beliefs: The final frontier in our quest for technology integration? Educational Technology Research and Development, 53(4), 25-39.

Ertmer, P. A. \& Ottenbreit-Leftwich, A. T. (2013). Removing obstacles to the pedagogical changes required by Jonassen's vision of authentic technology-enabled learning. Computers \& Education, 64, 175-182.

Ertmer, P., Ottenbreit-Leftwich, A., Sadik, O., Sendurur, E., \& Sendurur, P. (2012). Teacher beliefs and technology integration practices: A critical relationship. Computers \& Education, 59(2), 423-435.

Foster, J., Kelley, P., Pritz, S., \& Hodes, C. (2011). CTE's focus on continuous improvement. Techniques: Connecting Education and Careers (J1), 86(4), 28-31. 
Goktas, Y., Yildirim, S., \& Yildirim, Z. (2009). Main barriers and possible enablers of ICTs integration into preservice teacher education programs. Educational Technology \& Society, 12(1), 193-204.

Gray, L., Thomas, N., \& Lewis, L. (2010). Educational Technology in U.S. Public Schools: Fall 2008. U.S. Department of Education, NCES 2010-034.

Grunwald Associates LLC. (2013). Living and learning with mobile devices: What parents think about mobile devices for early childhood and K-12 learning. Retrieved on 20 May 2019 from http://www.grunwald.com/pdfs/Grunwald\%20Mobile\%20Study\%20public\% 20report.pdf

Gulek, J. C. \& Demirtas, H. (2005). Learning with technology: The impact of laptop use on student achievement. Journal of Technology, Learning, and Assessment, 3(2). Retrieved on 20 May 2019 from http://www.jtla.org

Harris, W. J. \& Smith, L. (2004). Laptop use by seventh grade students with disabilities: Perceptions of special education teachers. Orono, ME: Maine Education Policy Research Institute, University of Maine Office.

Hechter, R. P. \& Vermette, L. A. (2013). Technology integration in K-12 science classrooms: An analysis of barriers and implications. Themes in Science and Technology Education, 6(2), 73-90.

Hennessy, S., Ruthven, K., \& Brindley, S. (2007). Teacher perspectives on integrating ICT into subject teaching: Commitment, constraints, caution, and change. Journal of Curriculum Studies, 37, 155-192.

Hur, J. W., Shannon, D., \& Wolf, S. (2016). An investigation of relationships between internal and external factors affecting technology integration in classrooms. Journal of Digital Learning in Teacher Education, 32(3), 105-114.

Islam, M. S. \& Gronlund, A. (2016). An international literature review of 1: 1 computing in schools. Journal of Educational Change, 17(2), 191-222.

Kay, R., Knaack, L., \& Petrarca, D. (2009). Exploring teachers' perceptions of web-based learning tools. Interdisciplinary Journal of E-Learning and Learning Objects, 5(1), 27-50.

Keengwe, J., Onchwari, G., \& Wachira, P. (2008). Computer technology integration and student learning: barriers and promise. Journal of Science Education and Technology, 17(6), 560565.

Kilinc, E., Tarman, B., \& Aydin, H. (2018). Examining Turkish social studies teachers' beliefs about barriers to technology integration. TechTrends, 62, 221-223.

Kim, C., Kim, M. K., Lee, C., Spector, J. M., \& DeMeester, K. (2013). Teacher beliefs and technology integration. Teaching \& Teacher Education, 29, 76-85.

Kimmons, R. \& Hall, C. (2016). Toward a broader understanding of teacher technology integration beliefs and values. Journal of Technology and Teacher Education, 24(3), 309335.

Koh, J. H. L. \& Frick, T. W. (2009). Instructor and student classroom interactions during technology skills instruction for facilitating preservice teachers' computer self-efficacy. Journal of Educational Computing Research, 40(2), 211-228. 
Kopcha, T. J. (2012). Teachers' perceptions of the barriers to technology integration and practices with technology under situated professional development. Computers \& Education, 59(4), 1109-1121.

Lei, J. \& Zhao, Y. (2008). One-to-one computing: What does it bring to schools? Journal of Educational Computing Research, 39(2), 97-122.

Lowther, D. L., Inan, F. A., Strahl, J. D., \& Ross, S. M. (2008). Does technology integration "work" when key barriers are removed? Educational Media International, 45(3), 195213.

Miranda. H. P. \& Russell, M. (2012). Understanding factors associated with teacher-directed student use of technology in elementary classrooms: A structural equation modeling approach. British Journal of Educational Technology, 43(4), 652-666.

Mishra, P. \& Koehler, M. J. (2006). Technological pedagogical content knowledge: A framework for teacher knowledge. Teachers College Record, 108(6), 1017.

Moore-Hayes, C. (2011). Technology integration preparedness and its influence on teacherefficacy. Canadian Journal of Learning and Technology, 37(3). Retrieved on 20 May 2019 from https://www.cjlt.ca/index.php/cjlt/article/view/26351/19533

Morgan, P. \& Ritter, S. (2002). An experimental study of the effects of Cognitive Tutor ${ }^{\circledR}$ Algebra I on student knowledge and attitude. (Available from Carnegie Learning, Inc., 1200 Penn Avenue, Suite 150, Pittsburgh, PA 15222)

National Research Council. (2000). How people learn: Brain, mind, experience, and school (Expanded Edition). Washington, DC: National Academy Press.

Nikolopoulou, K. \& Gialamas, V. (2015). Barriers to the integration of computers in early childhood settings: Teachers' perceptions. Education and Information Technologies, 20(2), 285-301.

Ozdemir, M. (2010). Nitel veri analizi: Sosyal bilimlerde yontembilim sorunsali uzerine bir calisma. Eskisehir Osmangazi Universitesi Sosyal Bilimler Dergisi, 11(1), 323-343.

Patton, M. Q. (1990). Qualitative evaluation and research methods (2nd ed.). Thousand Oaks, CA: Sage.

Pennington, R. G. (2010). Computer-assisted instruction for teaching academic skills to students with autism spectrum disorders: A review of the literature. Focus on Autism and Other Developmental Disabilities, 25(4), 239-248.

Prasojo, L. D., Habibi, A., Yaakob, M. F. M., Mukminin, A., Haswindy, S., \& Sofwan, M. (2019). An explanatory sequential study on Indonesian principals' perceptions on ICT integration barriers. The Electronic Journal of e-Learning, 17(1), 1-10.

Rehmat, A. P. \& Bailey, J. M. (2014). Technology integration in a science classroom: Preservice teachers' perceptions. Journal of Science Education and Technology, 23(6), 744-755.

Reigeluth, C. \& Joseph, R. (2002). Beyond technology integration: the case for technology transformation. Educational Technology, 42(4), 9-16.

Rowan, B., Correnti, R., \& Miller, R. (2002). What large-scale survey research tells us about teacher effects on student achievement: Insights from the prospects study of elementary schools. Teachers College Record, 104(8), 1525-1567. 
Saine, P. (2012). iPods, iPads, and the Smartboard: Transforming literacy instruction and student learning. New England Reading Association Journal, 47(2), 74-79.

Scalise, K. (2016). Student collaboration and school educational technology: technology integration practices in the classroom. Journal on School Educational Technology, 11(4), 53-63.

Scott, P. \& Mouza, C. (2007). The impact of professional development on teacher learning, practice, and leadership skills: A study on the integration of technology in the teaching of writing. Journal of Educational Computing Research, 37(3), 229-266.

Shaltry, C., Henriksen, D., Wu, M. L., \& Dickson, W. P. (2013). Teaching pre-service teachers to integrate technology: Situated learning with online portfolios, classroom websites, and Facebook. TechTrends: Linking Research \& Practice to Improve Learning, 57(3), 20-25.

Sheninger, E. (2014). Digital leadership: Changing paradigms for changing times. Thousand Oaks, CA: Corwin \& Ontario Principal's Council.

Smith, H. J., Dinev, T., \& Xu, H. (2011). Information privacy research: An interdisciplinary review. MIS Quarterly, 35(4), 989-1015.

Stutzman, F., Gross, R., \& Acquisti, A. (2013). Silent listeners: The evaluation of privacy and disclosure on Facebook. Journal of Privacy and Confidentiality, 4(2), 7-41.

U.S. Department of Education. (2017). Reimagining the role of technology in education: 2017 National Education Technology Plan update. Washington, DC. The author.

Vatanartiran, S. \& Karadeniz, S. (2015). A needs analysis for technology integration plan: challenges and needs of teachers. Contemporary Educational Technology, 6(3), 206-220.

Wong, G. K. W. (2015). Understanding technology acceptance in pre-service teachers of primary mathematics in Hong Kong. Australasian Journal of Educational Technology, 31(6), 713-735.

Wood, E., Specht, J., Willoughby, T., \& Mueller, M. (2008). Integrating computer technology in early childhood education environments: issues raised by early childhood educators. The Alberta Journal of Educational Research, 54(2), 210-226.

Yildirim, A. \& Simsek, H. (2005). Sosyal bilimlerde nitel arastirma yontemleri (5 ${ }^{\text {th }}$ Edition). Ankara: Seckin.

Zehra, R. \& Bilwani, A. (2016). Perceptions of teachers regarding technology integration in classroom: A comparative analysis of elite and mediocre schools. Journal of Education and Educational Development, 3(1), 1-29.

Correspondence: Emre Dinc, Ph.D. Student, Department of Learning and Performance Systems, College of Education, Pennsylvania State University, State College, Pennsylvania, United States 